\title{
TP53 Mutation Analysis in Gastric Cancer and Clinical Outcomes of Patients with Metastatic Disease Treated with Ramucirumab/Paclitaxel or Standard Chemotherapy
}

Francesco Graziano ${ }^{1, *}$, Nicholas W. Fischer ${ }^{2}$, Irene Bagaloni ${ }^{3}$, Maria Di Bartolomeo ${ }^{4}$, Sara Lonardi ${ }^{5}\left({ }^{\circ}\right.$, Bruno Vincenzi $^{6}$, Giuseppe Perrone ${ }^{6}$, Lorenzo Fornaro ${ }^{7} \mathbb{(}$, Elena Ongaro ${ }^{8,9}$, Giuseppe Aprile ${ }^{10}$, Renato Bisonni ${ }^{11}$, Michele Prisciandaro ${ }^{4}\left(\mathbb{D}\right.$, David Malkin ${ }^{2,12,13}$, Jean Gariépy ${ }^{13,14}$, Matteo Fassan ${ }^{5}{ }^{(1)}$, Fotios Loupakis ${ }^{5}$, Donatella Sarti ${ }^{1}$, Michela Del Prete ${ }^{11}$, Vincenzo Catalano ${ }^{1}$, Paolo Alessandroni ${ }^{1}$, Mauro Magnani ${ }^{3(1)}$ and Annamaria Ruzzo ${ }^{3, *(1)}$

1 Medical Oncology Unit, Azienda, Ospedali Riuniti Marche Nord, 61121 Pesaro, Italy;

d.sarti@fastwebnet.it (D.S.); catalano_v@yahoo.it (V.C.); paolo.alessandroni@ospedalimarchenord.it (P.A.)

2 Genetics \& Genome Biology Program, The Hospital for Sick Children, Toronto, ON M5G 0A4, Canada; nick.fischer@mail.utoronto.ca (N.W.F.); david.malkin@sickkids.ca (D.M.)

3 Department of Biomolecular Sciences, Università degli Studi di Urbino, 61032 Fano, Italy; irene.bagaloni@uniurb.it (I.B.); mauro.magnani@uniurb.it (M.M.)

4 Department of Medical Oncology, Istituto Nazionale dei Tumori di Milano, 20133 Milan, Italy; Maria.DiBartolomeo@istitutotumori.mi.it (M.D.B.); michele.prisciandaro@istitutotumori.mi.it (M.P.)

5 Veneto Institute of Oncology IOV-IRCCS, 35128 Padova, Italy; sara.lonardi@iov.veneto.it (S.L.); matteo.fassan@unipd.it (M.F.); fotios.loupakis@iov.veneto.it (F.L.)

6 Department of Oncology, Campus Bio-Medico University, 00128 Rome, Italy; B.Vincenzi@unicampus.it (B.V.); g.perrone@unicampus.it (G.P.)

7 Unit of Medical Oncology 2, Azienda Ospedaliero-Universitaria Pisana, 56126 Pisa, Italy; lorenzo.fornaro@gmail.com

8 Department of Oncology, University and General Hospital, 33100 Udine, Italy; eleongaro@gmail.com

9 Unit of Medical Oncology and Cancer Prevention, Department of Medical Oncology, Centro di Riferimento Oncologico di Aviano (CRO) IRCCS, 33081 Aviano, Italy

10 Department of Oncology, San Bortolo General Hospital, 36100 Vicenza, Italy; giuseppe.aprile@aulss8.veneto.it

11 Medical Oncology Unit, Hospital of Fermo, 63900 Fermo, Italy; renato.bisonni@sanita.marche.it (R.B.); micheladelprete@gmail.com (M.D.P.)

12 Division of Hematology-Oncology, Department of Pediatrics, The Hospital for Sick Children, Toronto, ON M5G 1X8, Canada

13 Department of Medical Biophysics, University of Toronto, Toronto, ON M5G 1L7, Canada; jean.gariepy@utoronto.ca

14 Physical Sciences, Sunnybrook Research Institute, Toronto, ON M4N 3M5, Canada

* Correspondence: francesco.graziano@ospedalimarchenord.it (F.G.); annamaria.ruzzo@uniurb.it (A.R.); Tel.: +390-721364074 (F.G.); +390-722304957 (A.R.)

Received: 10 June 2020; Accepted: 22 July 2020; Published: 24 July 2020

Abstract: Loss of p53 promotes vascular endothelial growth factor (VEGF)-A up-regulation and the angiogenic potential of cancer cells. We investigated TP53 somatic mutations in 110 primary gastric adenocarcinomas of two retrospective metastatic series including 48 patients treated with second-line Ramucirumab/Paclitaxel and 62 patients who received first-line chemotherapy with Cisplatin or Oxaliplatin plus 5-Fluorouracil. Missense mutations were classified by tumor protein p53 (TP53) mutant-specific residual transcriptional activity scores (TP53 $3_{\text {RAS }}$ ) and used to stratify patients into two groups: transcriptionally $T P 53_{\text {Active }}$ and TP53 ${ }_{\text {Inactive. The primary endpoint was overall survival }}$ (OS). An additional analysis was addressed to measure VEGF/VEGF receptor 2 (VEGFR2) expression 


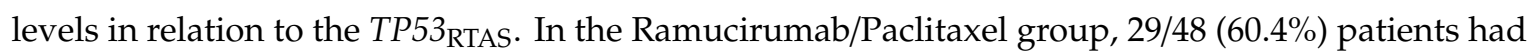
TP53 mutations. Ten patients with TP53 Inactive mutations showed better OS than carriers of other TP53 mutations. This effect was retained in the multivariate model analysis (Hazard Ratio $=0.29,95 \%$ confidence interval $=0.17-0.85, p=0.02)$. In the chemotherapy group, $41 / 62(66 \%)$ patients had TP53 mutations, and the 11 carriers of TP53 Inactive mutations showed the worst OS (Hazard Ratio $=2.64$, $95 \%$ confidence interval $=1.17-5.95, p=0.02$ ). VEGF-A mRNA expression levels were significantly increased in $T P 53_{\text {Inactive }}$ cases. Further studies are warranted to explore the effect of TP53 Inactive mutations in different anti-cancer regimens. This information would lead to new tailored therapy strategies for this lethal disease.

Keywords: gastric cancer; TP53; Ramucirumab; Paclitaxel; angiogenesis

\section{Introduction}

Tumor protein p53 (TP53) is a multifunctional tumor suppressor gene that is intimately involved in the control of target genes that regulate "healthy" biological processes, including cell-cycle arrest, apoptosis, senescence, energy metabolism, and antioxidant defense to prevent tumorigenesis [1]. In recent years, several experimental and clinical studies have also indicated a role for TP53 in the control of tumor angiogenesis [2]. This effect seems to be linked to cross-talk mechanisms between TP53, vascular endothelial growth factor (VEGF), and VEGF receptors.

A highly conserved and functional p53-binding site has been identified within the VEGF promoter and the p53 tumor suppressor downregulates VEGF expression [3]. Loss of TP53 in tumor cells enhances HIF-1alpha levels and augments HIF-1-dependent transcriptional activation of the VEGF gene in response to hypoxia [4]. TP53-deficient cancer cells were found to produce reactive oxygen species, which activated fibroblasts to mediate angiogenesis by VEGF both in-vivo and in-vitro [5]. The transcription factor E2F1 showed regulation of angiogenic activity via p53-dependent transcriptional control of VEGF expression [6]. In experimental models, mutant TP53 can up-regulate the transcription of VEGF receptor 2 (VEGFR2) by promoter remodeling [7]. These molecular mechanisms may explain analyses of human cancer tissues that have reported significant increases in VEGF expression levels in the presence of TP53 mutations [8-10]. Interestingly, in a large pan-cancer study [9], the association between VEGF up-regulation and TP53 mutants remained independent of HIF-1 and MDM2 overexpression. This translational background explains recent clinical findings in advanced cancer patients who had improved responses and survival outcomes after VEGF/VEGF receptor (VEGFR) inhibitor therapy mostly in tumors harboring a TP53 mutation [11-15].

The concept that TP53 alterations may represent a favorable biomarker for treating patients with anti-angiogenesis agents contrasts with previous findings from standard chemotherapy studies, where TP53 dysregulation was generally associated with poor clinical outcomes [16]. However, this is not surprising considering the multiple and widespread roles of TP53 and the prevalence of p53-associated mechanisms of chemoresistance [16].

Despite decades of research, the analysis of the TP53 status for predictive purposes in cancer therapy has not been implemented in routine clinical practice yet. Major limitations concern the lack of standardized methods for defining the TP53 status in tumor samples. Mutational analysis is more reliable than immunohistochemistry in solid tumors, but somatic TP53 mutations cannot be considered a homogeneous group inducing an on/off effect [1]. The majority of TP53 mutations occurring in human solid neoplasms are missense mutations with a large gradient of functional consequences [1]. Missense TP53 mutations can be classified for clinical purposes by considering the residual transcriptional activity score (TP53 ${ }_{\text {RTAS }}$ ) [17], derived from the results of a site-directed mutagenesis technique and yeast-based functional assay [18]. 
Gastric cancer ranks among the most frequently TP53-mutated solid tumors [19], and in recent years, the anti-VEGFR2 inhibitor Ramucirumab coupled with Paclitaxel has become standard second-line systemic therapy in this lethal disease [20]. Unfortunately, the magnitude and the duration of the survival gain in Ramucirumab/Paclitaxel treated patients are limited and the discovery of predictive markers would improve the selection of patients and allow the adoption of novel combination therapies [21].

This background prompted us to plan a translational study in patients with metastatic gastric cancer treated with Ramucirumab/Paclitaxel including the analysis of TP53 mutations and TP5 $3_{\text {RTAS }}$ in their tumor samples. The association between the mutant TP53 functional status and survival outcome was assessed and overall patient survival was the primary endpoint of the study. To better characterize the predictive impact of TP53 mutations, an additional retrospective cohort of patients treated with standard chemotherapy for advanced disease was included in the study.

\section{Results}

The overall study population consisted of 110 gastric cancer patients whose primary tumors were analyzed for TP53 mutations. The study group included 48 cases who underwent second-line Ramucirumab/Paclitaxel. In the control group, 62 patients were treated with standard first-line chemotherapy with a 5-Fluorouracil and a platinum compound (Cisplatin or Oxaliplatin).

\subsection{TP53 Analysis in Primary Gastric Tumors}

As shown in Table 1, 61 TP53 mutations were detected in total, including 47 missense mutations (77\%), 7 nonsense mutations (11.4\%), 4 frameshift mutations (6.6\%), 2 splice site mutations $(3.3 \%)$, and 1 in-frame deletion (1.7\%). Some "hot-spot" missense mutations occurred in more than one patient: p.R282W and p.G244D in two cases, p.R283H in three cases, p.R273C in five cases. Four patients showed a combination of two or more TP53 mutations in their tumor samples. Overall, 70 out of 110 patients showed tumor samples positive for TP53 mutations (63.6\%). The distribution of TP53 mutations (any type) according to clinical and pathological characteristics of patients and tumors is shown in Table 2. No significant association was found except for a prevalence of TP53 mutations in intestinal-type gastric cancer according to Lauren's classification (Table 2).

Table 1. Description of the tumor protein p53 (TP53) mutations detected in 70 patients.

\begin{tabular}{|c|c|c|c|c|c|c|}
\hline Mutation & $\begin{array}{l}\text { Amino Acid } \\
\text { Change }\end{array}$ & Effect & RTAS & $\begin{array}{l}\text { Functional } \\
\text { Classification }\end{array}$ & $\begin{array}{c}\text { Hg19 } \\
\text { Coordinates }\end{array}$ & $\begin{array}{c}\text { Therapy } \\
\text { Group }\end{array}$ \\
\hline $\mathrm{G}>\mathrm{T}$ & G245C & $\begin{array}{l}\text { missense } \\
\text { mutation }\end{array}$ & 0 & Inactive & 7577548 & R/P-SC \\
\hline$G>A$ & M246I & $\begin{array}{l}\text { missense } \\
\text { mutation }\end{array}$ & 0 & Inactive & 7577543 & $\mathrm{R} / \mathrm{P}$ \\
\hline $\mathrm{C}>\mathrm{T}$ & R248W & $\begin{array}{l}\text { missense } \\
\text { mutation }\end{array}$ & 0 & Inactive & 7577539 & R/P-SC \\
\hline $\mathrm{C}>\mathrm{T}$ & R282W & $\begin{array}{l}\text { missense } \\
\text { mutation }\end{array}$ & 0 & Inactive & 7577094 & $\mathrm{R} / \mathrm{P}^{2}-\mathrm{SC}$ \\
\hline$G>A$ & $\mathrm{R} 283 \mathrm{H}$ & $\begin{array}{l}\text { missense } \\
\text { mutation }\end{array}$ & 0 & Inactive & 7577090 & $\mathrm{R} / \mathrm{P}^{3}$ \\
\hline $\mathrm{C}>\mathrm{T}$ & T304I & $\begin{array}{l}\text { missense } \\
\text { mutation }\end{array}$ & 0 & Inactive & 7577027 & R/P-SC \\
\hline$G>A$ & G244D & $\begin{array}{l}\text { missense } \\
\text { mutation }\end{array}$ & 0.2 & Inactive & 7577550 & R/P-SC ${ }^{2}$ \\
\hline $\mathrm{C}>\mathrm{T}$ & $\mathrm{R} 273 \mathrm{C}$ & $\begin{array}{l}\text { missense } \\
\text { mutation }\end{array}$ & 0.4 & Inactive & 7577121 & $\mathrm{SC}^{5}$ \\
\hline
\end{tabular}


Table 1. Cont

\begin{tabular}{|c|c|c|c|c|c|c|}
\hline Mutation & $\begin{array}{c}\text { Amino Acid } \\
\text { Change }\end{array}$ & Effect & RTAS & $\begin{array}{l}\text { Functional } \\
\text { Classification }\end{array}$ & $\begin{array}{c}\text { Hg19 } \\
\text { Coordinates }\end{array}$ & $\begin{array}{c}\text { Therapy } \\
\text { Group }\end{array}$ \\
\hline$G>A$ & V216M & $\begin{array}{l}\text { missense } \\
\text { mutation }\end{array}$ & 1.2 & Active & 7578203 & SC \\
\hline $\mathrm{C}>\mathrm{T}$ & P151S & $\begin{array}{l}\text { missense } \\
\text { mutation }\end{array}$ & 5.2 & Active & 7578479 & SC \\
\hline$G>A$ & R175H & $\begin{array}{l}\text { missense } \\
\text { mutation }\end{array}$ & 9.2 & Active & 7578406 & R/P-SC \\
\hline $\mathrm{T}>\mathrm{C}$ & I195T & $\begin{array}{l}\text { missense } \\
\text { mutation }\end{array}$ & 11.4 & Active & 7578265 & SC \\
\hline$C>G$ & P177R & $\begin{array}{l}\text { missense } \\
\text { mutation }\end{array}$ & 12.0 & Active & 7578400 & $\mathrm{R} / \mathrm{P}$ \\
\hline $\mathrm{C}>\mathrm{T}$ & L194F & $\begin{array}{l}\text { missense } \\
\text { mutation }\end{array}$ & 12.0 & Active & 7578269 & SC \\
\hline $\mathrm{C}>\mathrm{T}$ & S260F & $\begin{array}{l}\text { missense } \\
\text { mutation }\end{array}$ & 12.6 & Active & 7577502 & SC \\
\hline$G>A$ & G105S & $\begin{array}{l}\text { missense } \\
\text { mutation }\end{array}$ & 15.0 & Active & 7579374 & SC \\
\hline $\mathrm{C}>\mathrm{T}$ & H214Y & $\begin{array}{l}\text { missense } \\
\text { mutation }\end{array}$ & 20.9 & Active & 7578209 & SC \\
\hline $\mathrm{C}>\mathrm{T}$ & H179Y & $\begin{array}{l}\text { missense } \\
\text { mutation }\end{array}$ & 22 & Active & 7578395 & $\mathrm{R} / \mathrm{P}$ \\
\hline$G>A$ & E180K & $\begin{array}{l}\text { missense } \\
\text { mutation }\end{array}$ & 22.8 & Active & 7578392 & $\mathrm{R} / \mathrm{P}$ \\
\hline $\mathrm{C}>\mathrm{T}$ & P177S & $\begin{array}{l}\text { missense } \\
\text { mutation }\end{array}$ & 26.9 & Active & 7578401 & SC \\
\hline$G>A$ & R282Q & $\begin{array}{l}\text { missense } \\
\text { mutation }\end{array}$ & 30.5 & Active & 7577093 & $\mathrm{R} / \mathrm{P}$ \\
\hline $\mathrm{C}>\mathrm{T}$ & P190S & $\begin{array}{l}\text { missense } \\
\text { mutation }\end{array}$ & 32.0 & Active & 7578281 & SC \\
\hline $\mathrm{C}>\mathrm{T}$ & R181C & $\begin{array}{l}\text { missense } \\
\text { mutation }\end{array}$ & 32.4 & Active & 7578389 & $\mathrm{R} / \mathrm{P}$ \\
\hline$G>A$ & $\mathrm{D} 228 \mathrm{~N}$ & $\begin{array}{l}\text { missense } \\
\text { mutation }\end{array}$ & 40.7 & Active & 7577599 & SC \\
\hline$G>A$ & C229Y & $\begin{array}{l}\text { missense } \\
\text { mutation }\end{array}$ & 69.3 & Active & 7577595 & SC \\
\hline $\mathrm{C}>\mathrm{T}$ & R175C & $\begin{array}{l}\text { missense } \\
\text { mutation }\end{array}$ & 72.5 & Active & 7578407 & $\mathrm{R} / \mathrm{P}$ \\
\hline $\mathrm{C}>\mathrm{T}$ & L252F & $\begin{array}{l}\text { missense } \\
\text { mutation }\end{array}$ & 76.7 & Active & 7577527 & SC \\
\hline$G>A$ & $\mathrm{R} 379 \mathrm{H}$ & $\begin{array}{l}\text { missense } \\
\text { mutation }\end{array}$ & 77.8 & Active & 7572974 & SC \\
\hline $\mathrm{C}>\mathrm{T}$ & $\mathrm{H} 115 \mathrm{Y}$ & $\begin{array}{l}\text { missense } \\
\text { mutation }\end{array}$ & 81.1 & Active & 7679344 & $\mathrm{R} / \mathrm{P}$ \\
\hline $\mathrm{G}>\mathrm{A}$ & G356R & $\begin{array}{l}\text { missense } \\
\text { mutation }\end{array}$ & 88.3 & Active & 7573961 & SC \\
\hline $\mathrm{C}>\mathrm{T}$ & S116F & $\begin{array}{l}\text { missense } \\
\text { mutation }\end{array}$ & 90.7 & Active & 7579340 & SC \\
\hline$G>A$ & V225I & $\begin{array}{l}\text { missense } \\
\text { mutation }\end{array}$ & 91.7 & Active & 7577608 & $\mathrm{R} / \mathrm{P}$ \\
\hline
\end{tabular}


Table 1. Cont.

\begin{tabular}{|c|c|c|c|c|c|c|}
\hline Mutation & $\begin{array}{c}\text { Amino Acid } \\
\text { Change }\end{array}$ & Effect & RTAS & $\begin{array}{l}\text { Functional } \\
\text { Classification }\end{array}$ & $\begin{array}{c}\text { Hg19 } \\
\text { Coordinates }\end{array}$ & $\begin{array}{c}\text { Therapy } \\
\text { Group }\end{array}$ \\
\hline$G>A$ & A353T & $\begin{array}{l}\text { missense } \\
\text { mutation }\end{array}$ & 96.9 & Active & 7573970 & SC \\
\hline $\mathrm{C}>\mathrm{T}$ & L383F & $\begin{array}{l}\text { missense } \\
\text { mutation }\end{array}$ & 97.5 & Active & 7572962 & $\mathrm{R} / \mathrm{P}$ \\
\hline $\mathrm{C}>\mathrm{T}$ & S90F & $\begin{array}{l}\text { missense } \\
\text { mutation }\end{array}$ & 99.2 & Active & 7579418 & SC \\
\hline $\mathrm{G}>\mathrm{A}$ & R174K & $\begin{array}{l}\text { missense } \\
\text { mutation }\end{array}$ & 102.0 & Active & 7578409 & SC \\
\hline $\mathrm{C}>\mathrm{T}$ & P222L & $\begin{array}{l}\text { missense } \\
\text { mutation }\end{array}$ & 102.9 & Active & 7578184 & $\mathrm{R} / \mathrm{P}$ \\
\hline $\mathrm{G}>\mathrm{A}$ & E294K & $\begin{array}{l}\text { missense } \\
\text { mutation }\end{array}$ & 107.7 & Active & 7577058 & SC \\
\hline $\mathrm{G}>\mathrm{A}$ & S261N & $\begin{array}{l}\text { missense } \\
\text { mutation }\end{array}$ & 108.0 & Active & 7577499 & SC \\
\hline $\mathrm{C}>\mathrm{T}$ & S314F & $\begin{array}{l}\text { missense } \\
\text { mutation }\end{array}$ & 110.0 & Active & 7576905 & SC \\
\hline$G>A$ & V217M & $\begin{array}{l}\text { missense } \\
\text { mutation }\end{array}$ & 116.0 & Active & 7578200 & SC \\
\hline $\mathrm{G}>\mathrm{A}$ & G226D & $\begin{array}{l}\text { missense } \\
\text { mutation }\end{array}$ & 120.1 & Active & 7577604 & $\mathrm{R} / \mathrm{P}$ \\
\hline $\mathrm{C}>\mathrm{T}$ & R290C & $\begin{array}{l}\text { missense } \\
\text { mutation }\end{array}$ & 134.2 & Active & 7577070 & SC \\
\hline $\mathrm{C}>\mathrm{T}$ & T329I & $\begin{array}{l}\text { missense } \\
\text { mutation }\end{array}$ & 138.6 & Active & 7576860 & SC \\
\hline $\mathrm{C}>\mathrm{T}$ & T312I & $\begin{array}{l}\text { missense } \\
\text { mutation }\end{array}$ & 139.8 & Active & 7576911 & $\mathrm{R} / \mathrm{P}$ \\
\hline $\mathrm{G}>\mathrm{A}$ & A307T & $\begin{array}{l}\text { missense } \\
\text { mutation }\end{array}$ & 142.7 & Active & 7577019 & SC \\
\hline $\mathrm{C}>\mathrm{T}$ & P309S & $\begin{array}{l}\text { missense } \\
\text { mutation }\end{array}$ & 151.2 & Active & 7576920 & $\mathrm{R} / \mathrm{P}$ \\
\hline $\mathrm{C}>\mathrm{T}$ & R196* & $\begin{array}{l}\text { nonsense } \\
\text { mutation }\end{array}$ & - & Other & 7578263 & SC \\
\hline $\mathrm{C}>\mathrm{T}$ & Q192* & $\begin{array}{l}\text { nonsense } \\
\text { mutation }\end{array}$ & - & Other & 7578275 & SC \\
\hline $\mathrm{C}>\mathrm{T}$ & $\mathrm{R} 342$ * & $\begin{array}{l}\text { nonsense } \\
\text { mutation }\end{array}$ & - & Other & 7574003 & $\mathrm{R} / \mathrm{P}$ \\
\hline $\mathrm{C}>\mathrm{T}$ & Q317* & $\begin{array}{l}\text { nonsense } \\
\text { mutation }\end{array}$ & - & Other & 7576897 & SC \\
\hline $\mathrm{C}>\mathrm{T}$ & $\mathrm{R} 306^{*}$ & $\begin{array}{l}\text { nonsense } \\
\text { mutation }\end{array}$ & - & Other & 7577002 & $\mathrm{R} / \mathrm{P}$ \\
\hline $\mathrm{C}>\mathrm{T}$ & Q165* & $\begin{array}{l}\text { nonsense } \\
\text { mutation }\end{array}$ & - & Other & 7578437 & SC \\
\hline$C>G$ & Y107 * & $\begin{array}{l}\text { nonsense } \\
\text { mutation }\end{array}$ & - & Other & 7579366 & $\mathrm{R} / \mathrm{P}$ \\
\hline $\mathrm{GTC}>\mathrm{GT}$ & L93X & $\begin{array}{l}\text { reading } \\
\text { frameshift }\end{array}$ & - & Other & 7579408 & $\mathrm{R} / \mathrm{P}$ \\
\hline $\begin{array}{c}\mathrm{tGCCCCСаc} \\
> \\
\mathrm{tTCCССССас}\end{array}$ & СРH176-178FPPX & $\begin{array}{l}\text { reading } \\
\text { frameshift }\end{array}$ & - & Other & 7578397-403 & $\mathrm{SC}$ \\
\hline
\end{tabular}


Table 1. Cont.

\begin{tabular}{ccccccc}
\hline Mutation & $\begin{array}{c}\text { Amino Acid } \\
\text { Change }\end{array}$ & Effect & RTAS & $\begin{array}{c}\text { Functional } \\
\text { Classification }\end{array}$ & $\begin{array}{c}\text { Hg19 } \\
\text { Coordinates }\end{array}$ & $\begin{array}{c}\text { Therapy } \\
\text { Group }\end{array}$ \\
\hline $\begin{array}{c}\text { GCCCCCTCC } \\
>\end{array}$ & APS88-90VPS & $\begin{array}{c}\text { reading } \\
\text { frameshift }\end{array}$ & - & Other & $7579419-424$ & R/P \\
\hline gCCCCTCcC & R209X & $\begin{array}{c}\text { reading } \\
\text { frameshift }\end{array}$ & - & Other & $7578221-223$ & SC \\
\hline CCT $>-$ & P190- & $\begin{array}{c}\text { inframe } \\
\text { deletion }\end{array}$ & - & Other & $75782780-281$ & R/P \\
\hline G $>$ T & - & $\begin{array}{l}\text { acceptor } \\
\text { intron } 8\end{array}$ & - & Other & 7576927 & R/P \\
\hline G $>$ A & - & $\begin{array}{l}\text { acceptor } \\
\text { intron } 9\end{array}$ & - & Other & 7576852 & SC \\
\hline
\end{tabular}

Abbreviations: RTAS, residual transcriptional activity score; SC, standard chemotherapy; R/P, Ramucirumab/ Paclitaxel; hg19, Genome Reference Consortium Human Build 37 (GRCh37) coordinates; Legend: ${ }^{2}$ mutation in two cases; ${ }^{3}$ mutation in three cases; ${ }^{5}$ mutation in five cases; ${ }^{*}$ stop codon.

Table 2. Characteristics and distribution of the 110 patients according to treatments and TP53 status.

\begin{tabular}{|c|c|c|c|c|c|c|c|}
\hline \multicolumn{8}{|c|}{ Number of Patients (\%) } \\
\hline \multirow[t]{2}{*}{ Variable } & \multicolumn{2}{|c|}{ Ramucirumab/Paclitaxel } & \multicolumn{2}{|c|}{ Standard Chemotherapy } & \multicolumn{2}{|c|}{ Total } & \multirow[t]{2}{*}{$p$-Value } \\
\hline & TP53 wt & TP53 mut & TP53 wt & TP53 mut & TP53 wt & TP53 mut & \\
\hline \multicolumn{8}{|l|}{ Age } \\
\hline$>65$ years & $12(63.2)$ & $15(51.7)$ & $11(52.4)$ & $20(48.8)$ & $23(57.5)$ & $35(50)$ & 0.5 \\
\hline$\leq 65$ years & $7(36.8)$ & $14(48.3)$ & $10(47.6)$ & $21(51.2)$ & $17(42.5)$ & $35(50)$ & \\
\hline \multicolumn{8}{|l|}{ Gender } \\
\hline Male & $11(57.9)$ & $16(55.2)$ & $15(71.4)$ & $23(56.1)$ & $26(65)$ & $39(55.7)$ & 0.4 \\
\hline Female & $8(42.1)$ & $13(44.8)$ & $6(28.6)$ & $18(43.9)$ & $14(35)$ & $31(44.3)$ & \\
\hline \multicolumn{8}{|l|}{ Grading } \\
\hline $1-2$ & $16(84.2)$ & $20(68.9)$ & $14(66.6)$ & $24(58.5)$ & $30(75)$ & $44(62.8)$ & 0.2 \\
\hline 3 & $3(15.8)$ & $9(31.1)$ & $7(33.4)$ & $17(41.5)$ & $10(25)$ & $26(37.2)$ & \\
\hline \multicolumn{8}{|c|}{ Peritoneum involvement } \\
\hline Positive & $10(52.6)$ & $16(55.2)$ & $3(14.3)$ & $14(34.2)$ & $13(42.5)$ & $30(42.8)$ & 0.4 \\
\hline Negative & $9(47.4)$ & $13(44.8)$ & $18(85.7)$ & $27(65.8)$ & $27(67.5)$ & $40(57.2)$ & \\
\hline \multicolumn{8}{|l|}{ ECOG PS } \\
\hline 0 & $9(47.3)$ & $18(62.1)$ & $18(85.7)$ & $24(58.5)$ & $27(67.5)$ & $42(60)$ & 0.5 \\
\hline $1-2$ & $10(52.7)$ & $11(37.9)$ & $3(14.3)$ & $17(41.5)$ & $13(42.5)$ & $28(40)$ & \\
\hline \multicolumn{8}{|c|}{ Lauren's histology } \\
\hline Intestinal & $12(63.2)$ & $23(79.3)$ & $11(52.4)$ & $32(78)$ & $23(57.6)$ & $55(78.5)$ & 0.02 \\
\hline Diffuse & $7(36.8)$ & $6(20.7)$ & $10(47.6)$ & $9(22)$ & $17(42.5)$ & $15(21.5)$ & \\
\hline \multicolumn{8}{|l|}{ Grading } \\
\hline $1-2$ & $10(52.6)$ & $19(65.5)$ & $12(57.1)$ & $31(75.6)$ & $22(55)$ & $50(71.4)$ & 0.09 \\
\hline 3 & $9(47.4)$ & $10(34.5)$ & $9(42.9)$ & $10(24.4)$ & $18(45)$ & $20(28.6)$ & \\
\hline \multicolumn{8}{|c|}{ Primary tumor resected } \\
\hline Yes & $12(63.2)$ & $9(31.1)$ & $10(52.4)$ & $18(43.9)$ & $22(55)$ & $27(38.5)$ & 0.1 \\
\hline No & $7(36.8)$ & $20(68.9)$ & $11(47.6)$ & $23(56.1)$ & $18(45)$ & $43(61.5)$ & \\
\hline \multicolumn{8}{|c|}{ Primary tumor site } \\
\hline Cardia & $7(36.8)$ & $11(37.9)$ & $9(42.9)$ & $15(36.5)$ & $16(40)$ & $26(37.1)$ & 0.8 \\
\hline non-cardia & $12(63.2)$ & $18(62.1)$ & $12(57.1)$ & $26(63.5)$ & $24(60)$ & 44 (62.9) & \\
\hline
\end{tabular}

Abbreviations: wt, wild-type; mut, mutated; ECOG PS, Eastern Cooperative Group Performance Status. 


\subsection{Classification of TP53 Mutations and Study Groups}

Results of the residual transcriptional activity score (RTAS) analysis for missense mutations

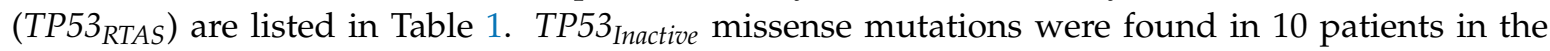
Ramucirumab/Paclitaxel group and 11 patients in the chemotherapy control group. The remaining 49 TP53 mutation-positive patients were classified as carriers of a TP53 Active missense mutation and carriers of non-missense mutations (nonsense, frameshift, splice-site, and in-frame deletions). TP53 Active missense mutation carriers were in 13 cases in the Ramucirumab/Paclitaxel group and 25 cases in the chemotherapy control group. Non-missense mutations carriers totaled 5 in the Ramucirumab/Paclitaxel group and 6 in the chemotherapy control group.

\subsection{Ramucirumab/Paclitaxel Second-Line Therapy and TP53 Analysis}

In the 48 patients of the study group, the results of the second-line therapy showed a $20.8 \%$ overall response rate (10 patients with a partial response) and a median overall survival (OS) time of 8.4 months (5-8.8 months 95\% CI). No significant association was detected between TP53 mutations and tumor response. Partial responses occurred in three patients with TP53 Inactive missense mutations, in two patients with TP53 non-missense mutations, and in five patients with wild-type TP53 $3_{\text {RTAS }}$ status.

Median OS times were: 9.5 months $(9.0-10.7$ months $95 \% \mathrm{CI})$ in carriers of TP53 ${ }_{\text {Inactive }}$ missense mutations; 8.6 months (5.9-9.9 months 95\% CI) in carriers of other TP53 mutations; 6.0 months (3.2-8.5 months $95 \% \mathrm{CI})$ in carriers of TP53 $3_{\text {Active }}$ missense mutations; 4.5 months $(4.1-8.2$ months $95 \% \mathrm{CI})$ in patients without TP53 mutations. A significant difference was observed between the survival curves of the four groups using the log-rank test (Figure 1). The analysis of hazard ratios with $95 \%$ CIs indicates the survival advantage of carriers of TP53 Inactive missense mutations over other groups except for carriers of other TP53 mutations (Figure 1). The favorable effect of the TP53 Inactive mutational status was retained in the multivariate model (Figure 2).

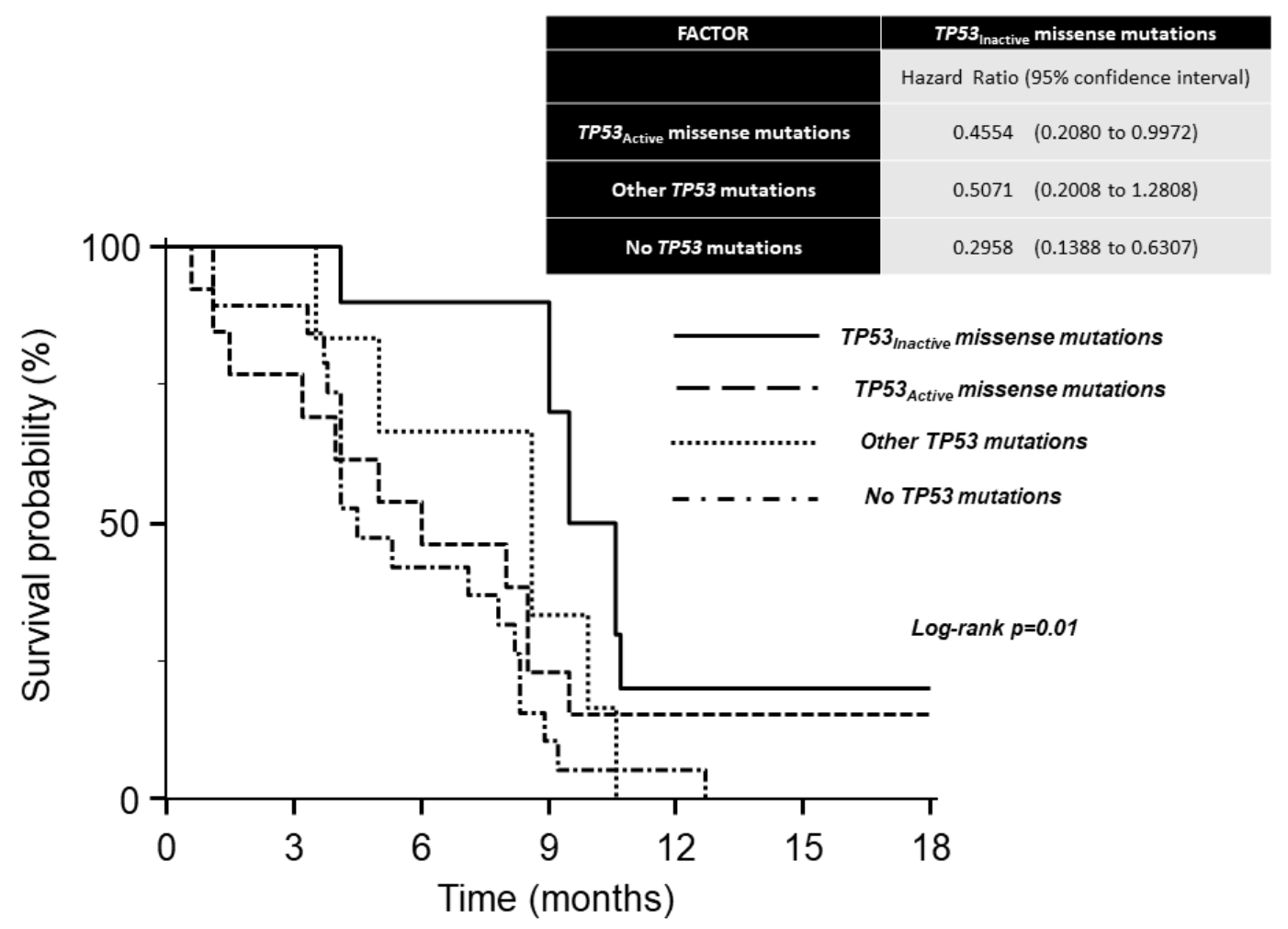

Figure 1. Kaplan-Meier survival curves of Ramucirumab/Paclitaxel second-line therapy in 48 patients with metastatic gastric cancer. 

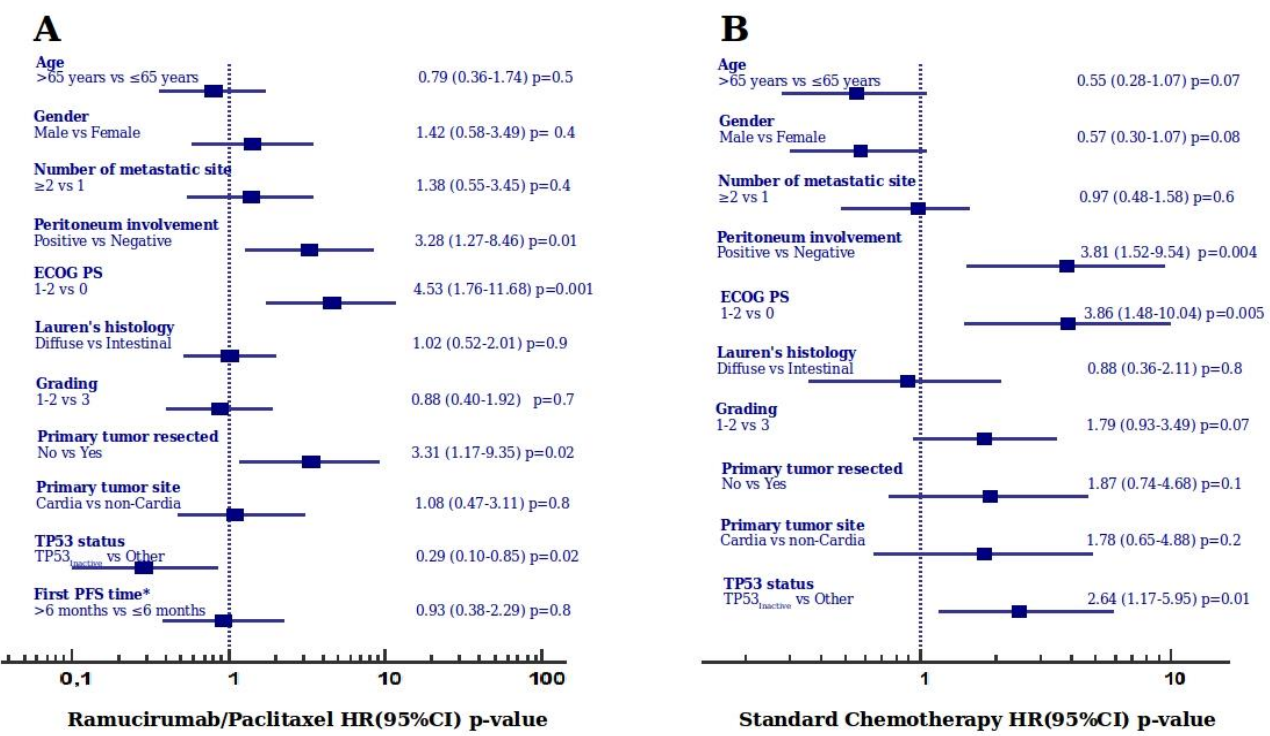

Figure 2. Results of the multivariate model analysis for overall survival in the Ramucirumab/Paclitaxel (A) and Standard Chemotherapy (B) treatment groups. Abbreviations: HR, Hazard Ratio; CI, confidence interval; ECOG PS, Eastern Cooperative Group Performance Status; PFS, progression-free survival. First PFS time* is a variable for second-line Ramucirumab/Paclitaxel therapy only.

\subsection{Standard First-Line Chemotherapy and TP53 Analysis}

In the 62 patients of the control group, the results of the first-line chemotherapy showed a $51.6 \%$ overall response rate ( 28 partial responses and 4 complete responses). The median OS time was 9 months (95\% Cls $=8-10.2$ months). No significant association was detected between TP53 mutations and tumor response. Partial responses occurred in 5 patients $(45 \%)$ with TP53 Inactive $_{\text {missense mutations, }}$ in 13 patients (52\%) with TP53 Active missense mutations, in 2 patients $(40 \%)$ with TP53 non-missense mutations, and in 8 patients (38\%) without TP53 mutations. Complete responses were observed in one patient in each of the four groups. Median OS times were: 8 months (4.3-9.0 months $95 \% \mathrm{CI}$ ) in

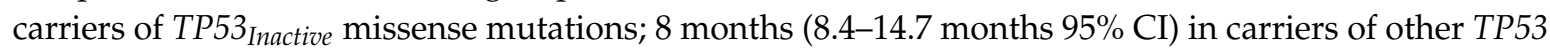
mutations; 8.5 months (5.7-10 months $95 \% \mathrm{CI}$ ) in carriers of TP53 ${ }_{\text {Active }}$ missense mutations; 10.6 months (8.4-14.7 months 95\% CI) in patients without TP53 mutations. A comparison of the survival curves using the log-rank test showed significant differences between the four groups (Figure 3).

The analysis of hazard ratios with $95 \%$ CIs reveals a detrimental effect of the TP53 $3_{\text {Inactive }}$ missense mutations status in comparison to patients without TP53 mutations (Figure 3). The adverse effect of the TP53 Inactive mutational status was retained in the multivariate model (Figure 2). 


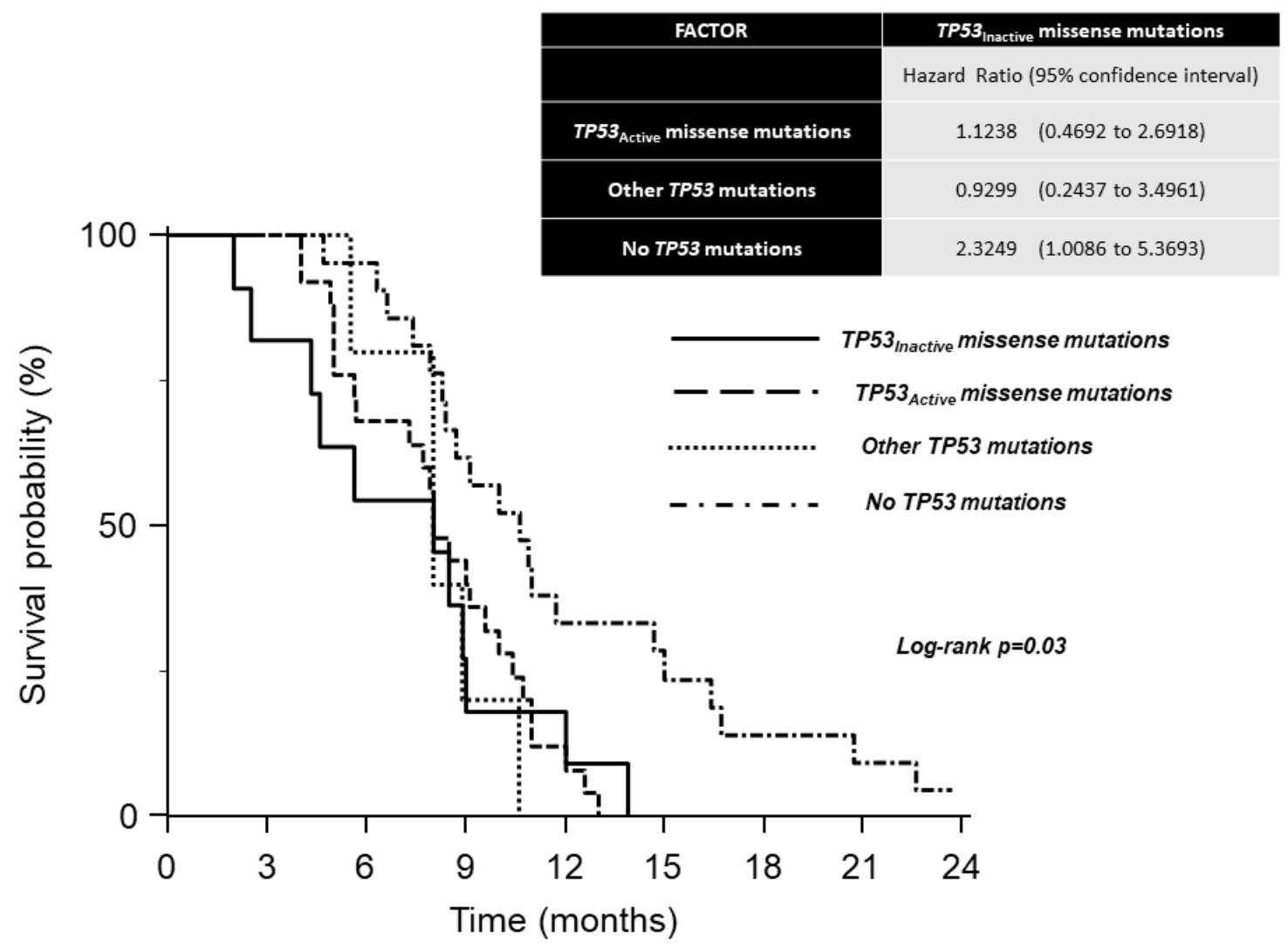

Figure 3. Kaplan-Meier survival curves of first-line combination chemotherapy in 62 patients with metastatic gastric cancer.

\subsection{VEGF/VEGFR Analysis and TP53 Mutational Status in Gastric Cancer Tissues}

Since Ramucirumab is a VEGFR2 antagonist that blocks the binding of VEGF-A, VEGF-C, and VEGF-D, we analyzed the mRNA expression and copy number alterations of these genes in gastric adenocarcinomas. VEGF- $A$ gene gain was significantly more frequent in tumors with TP53 ${ }_{\text {Inactive }}$ mutations (58.1\%) as compared to tumors with TP53 Active mutations $(35.7 \%)$ or wild-type p53 $(13.4 \%)$ ( $p=0.019$ and $p<0.0001$, respectively). Importantly, VEGF-A mRNA expression was correspondingly higher in the TP53 $3_{\text {Inactive }}$ group as compared to tumors with TP53 ${ }_{\text {Active }}$ or wild-type p53 ( $p=0.047$ and $p=0.0039$, respectively). While no differences in the gene loss of VEGF- $A$ were observed between these groups, the deletion of VEGF-C and VEGFR2 occurred less often in the wild-type p53 group as compared to the TP53 mutation subgroups ( $p<0.01$ and $p<0.0001$, respectively), although this did not translate to significant differences in mRNA expression levels. Loss of VEGF-D occurred most frequently in the TP53 $3_{\text {Inactive }}$ group (32.6\%), with significantly fewer deletion events in wild-type p53 tumors $(p<0.0001)$, however, there were no differences in mRNA expression levels (Figure 4). Together, these findings support a mechanism exclusive to tumors with transcriptionally inactive p53 mutants, indicating a reliance on increased VEGF-A production to drive tumorigenesis. 


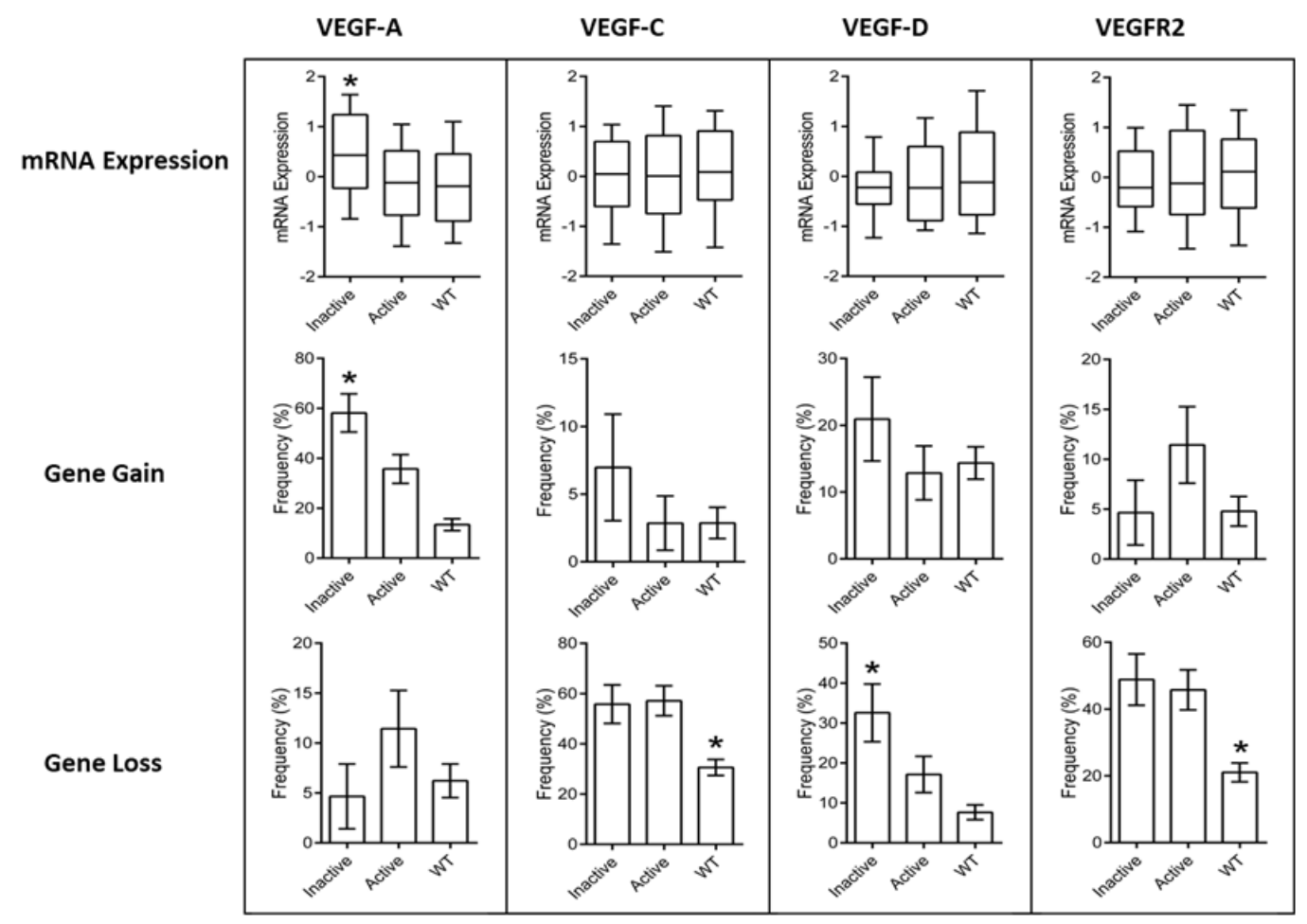

Figure 4. Plots of vascular endothelial growth factor (VEGF)/VEGF receptor 2 (VEGFR2) analysis in gastric cancer tissues. Data were collected from the TCGA PanCancer Atlas. * indicates statistically significant differences between groups as described in the text.

\section{Discussion}

The results of this study support the hypothesis that TP53 may be a valuable biomarker that can identify metastatic gastric cancer patients with the greatest benefit from an anti-angiogenic, anti-VEGFR2 systemic therapy. Importantly, the positive therapeutic effect, being associated with a specific group of transcriptionally inactive TP53 missense mutations (TP53 $3_{R T A S}<1 \%$ ) would simplify the development of a genetic test for further investigations, and hopefully, for routine clinical practice. This finding contributes to a mounting body of evidence linking TP53 mutational status to anti-angiogenic treatment clinical outcomes in patients with advanced cancers [11-15].

So far, the loss of function of the TP53 tumor suppressor gene has been considered an unfavorable prognostic feature in patients with solid tumors [22]. Uncontrolled cell-cycle regulation, senescence, metabolism, and apoptosis in TP53 "null" neoplasms may explain this association [22]. However, the clinical impact of TP53 dysregulation may vary in patients undergoing anti-cancer systemic therapies, which could depend on differences in the mechanisms of action of anti-cancer agents [16]. Pre-clinical and translational studies have found links between TP53 loss of function and resistance to DNA damaging agents like platinum compounds and anthracyclines [16]. Conversely, tumors with loss of normal TP53 function may be even more sensitive to anti-cancer agents like Paclitaxel that stabilizes tubulin polymerization resulting in the arrest of mitosis and the induction of TP53-independent apoptosis [23,24]. It has been also demonstrated that Paclitaxel, especially in fractionated regimens, exploits anti-angiogenic mechanisms of action [25] Together, these chemotherapy-related aspects, in addition to pre-clinical and clinical studies linking TP53 mutations to the VEGF pathway [5-8] and anti-VEGF/VEGFR systemic therapies [9-15], contribute to explaining the favorable results of the Ramucirumab/Paclitaxel combination in metastatic gastric cancers harboring TP53 mutations.

In the present study, we performed a combined analysis of TP53 RTAS missense mutations and VEGF-A and VEGFR2 expression levels in gastric adenocarcinoma tumor tissue samples. The results indicate a significant VEGF-A up-regulation in tumor samples with TP53 Inactive and unmodified 
VEGFR2 expression. These results parallel findings in previous analyses [3-7]. In a large pan-cancer cohort of 7525 samples, Li AM et al. [9] demonstrated up-regulated VEGF-A transcript levels in tumors with TP53 mutations, particularly in adenocarcinomas, regardless of their organ of origin, while VEGFR2 expression levels were not significantly modified by TP53 mutational status or reduced in squamous carcinomas. Since VEGF-A is considered the most potent angiogenic ligand and it exhibits the highest binding affinity for VEGFR2 [26], it is plausible that VEGF-A up-regulation is a major mechanism underlying the positive clinical impact of TP53 mutants on anti-VEGF/VEGFR2 therapies.

Intriguingly, additional mechanisms may also explain the positive clinical interaction between chemotherapy, anti-angiogenics, and TP53 status. In a translational analysis from a randomized trial in endometrial cancer, a remarkable survival benefit was found in the bevacizumab/chemotherapy arm in the presence of TP53 mutations causing loss of function or "null" phenotype [14]. Results from cell models suggested a mechanism of synthetic lethality derived from the effects of agents like bevacizumab to abrogate cell cycle checkpoints in the absence of p53 by blocking signaling downstream of tyrosine kinases [14]. This causes the premature entry of cancer cells into vulnerable phases of the cell cycle where chemotherapy agents are most effective.

The majority of somatic TP53 mutations detected in human cancers are missense mutations [1,2]. These mutations, which arise from a point mutation in a single nucleotide, can result in amino acid changes that can lead to highly variable degrees of functional consequences. For example, an amino acid may be replaced by another amino acid with very similar chemical properties, resulting in a protein that still functions normally. In contrast, some amino acid changes may cause greater dysfunction or non-functional protein products. To overcome difficulties in the interpretation of TP53 mutational analysis, we adopted a functional classification of TP53 missense mutations based on a transcriptional activity score as the result of a site-directed mutagenesis technique and yeast-based functional assay $[17,18]$. Tumors harboring TP53 Inactive missense mutations showed the longest survival time and the greatest benefit from the anti-VEGFR2 Ramucirumab/Paclitaxel systemic therapy. The analysis of survival curves suggests that tumors with TP53 non-missense mutations may also obtain some survival benefit from Ramucirumab/Paclitaxel (non-significant 52\% risk reduction in the comparison with the wild-type group). Notably, TP53 non-missense mutants producing the loss of the protein product do not display specific properties of some missense mutations (i.e., hotspot mutants) with augmented oncogenic potential. This effect may be caused by their capacity to impair the wild-type allele (dominant-negative effects) and/or by specific gain-of-function effects $[25,26]$. Many missense TP53 mutants are expressed as stable proteins that exert dominant-negative effects by interfering with the remaining wild-type p53 protein copies through the formation of hetero-tetramers. A "prion-like" effect of some p53 mutants has also been shown to inactive wild-type p53 in vitro by forcing the wild-type protein to adopt a denatured, mutant-like conformation [2,27]. As a result of the gain-of-function effect, some TP53 missense mutants were found to promote tumor angiogenic pathways, whereas TP53 deletion or truncating events did not [28,29].

Our analysis of TP53 mutations in relation to the clinical characteristics and pathological features of gastric adenocarcinomas in the present study population is supported by pivotal studies on the molecular classification of gastric cancer [30]. TP53 mutations characterize the most common of four molecular subtypes of gastric adenocarcinomas, defined by chromosomal instability. This genomically unstable subtype is associated with an intestinal histotype according to Lauren's classification, and a homogenous distribution along the different gastric sites.

\section{Materials and Methods}

The study group consisted of metastatic gastric cancer patients who received second-line systemic therapy with Ramucirumab $8 \mathrm{mg} / \mathrm{kg}$ (given on day 1 and 15) and Paclitaxel $80 \mathrm{mg} / \mathrm{m}^{2}$ (given on day 1,8 , and 15), both administered intravenously every 28 days. The cohort study was retrospective and performed among participating Institutions in the RAMoss analysis [31], which retrospectively 
evaluated the safety and efficacy of Ramucirumab among Italian patients failing first-line treatment for advanced gastric cancer.

The control group comprised metastatic gastric cancer patients who underwent Cisplatin or Oxaliplatin plus 5-Fluorouracil systemic chemotherapy. This retrospective cohort was implemented from consecutive cases included in a large three-Institution database [32]. In both cohorts, the study inclusion required the availability of primary tumor tissue samples. The study was performed in accordance with the reporting recommendations for tumor marker prognostic studies (REMARK) guidelines [33]. All patient information and pathology materials were collected under a protocol approved by the Regional Ethical Committee (the protocol number is 2016-0374MN).

\subsection{Samples and Nucleic Acids Extraction}

A sample of 4-6 10- $\mu \mathrm{m}$ sections from formalin-fixed, paraffin-embedded specimens were obtained from patient tumors and matched normal tissues. Before cutting sections for total nucleic acid isolation, an additional slide was prepared for hematoxylin-eosin staining and the pathologists identified representative areas with an almost complete representation of tumor infiltration. Tissues were micro-dissected and placed in a $1.5 \mathrm{~mL}$ reaction tube containing $1 \mathrm{~mL}$ xylene to remove paraffin. DNA was extracted using the RecoverAll ${ }^{\mathrm{TM}}$ Multi-Sample RNA/DNA Isolation Workflow (Invitrogen ${ }^{\mathrm{TM}}$ by Thermo Fisher, Foster City, CA, USA) according to the manufacturer's instructions. DNA concentration and purity were measured using the NanoDrop 1000 spectrophotometer (Nanodrop Technologies, Rockland, DE, USA).

\subsection{Amplicons Library Preparation and Next-Generation Sequencing (NGS) for TP53 Analysis}

A custom panel (IAD_119861) including the TP53 gene coding and UTR regions was designed using the Ion AmpliSeq ${ }^{\mathrm{TM}}$ Designer software (Thermo Fisher, Foster City, CA, USA). The panel was made up of 35 amplicons and ensured $82 \%$ of coverage for DNA from formalin-fixed paraffin-embedded (FFPE) tissues. Library preparation was performed using the Ion AmpliSeq Library Kit Plus according to the manufacturer's instructions. Libraries were generated using $40 \mathrm{ng}$ of DNA from tumor FFPE sections and indexed using the Ion Xpress Barcode Adapter Kit. Library purification was carried out using the AMPure ${ }^{\mathrm{TM}}$ XP Reagent (Beckman Coulter, Brea, CA, USA) on the DynaMag ${ }^{\mathrm{TM}}-2$ Magnet. Qubit $^{\mathrm{TM}} 4$ Fluorometer (Invitrogen ${ }^{\mathrm{TM}}$, by Thermo Fisher, Foster City, CA, USA) was used to quantify amplicons libraries. After dilution of all samples at $100 \mathrm{pM}$, libraries were pooled for emulsion PCR on the Ion OneTouch ${ }^{\mathrm{TM}} 2$ instrument, using the Ion S5 ${ }^{\mathrm{TM}}$ Template OT2 kit, according to the manufacturer's instructions. The Ion Sphere ${ }^{\mathrm{TM}}$ Particles were enriched using the Ion OneTouch ${ }^{\mathrm{TM}}$ Enrichment System and the template was sequenced on the Ion Torrent S5 platform using the Ion $540^{\mathrm{TM}}$ Chip (cat.no.A27766) following the manufacturer's instruction. All of these instruments and reagents were supplied by Thermo Fisher (Foster City, CA, USA). Read alignment was performed using hg19 (GRCh37) as the reference genome. Variant call files (VCF) were generated by the Variant Caller v.5 plugin preinstalled in the Torrent Suite and analyzed with the Ion Reporter ${ }^{\mathrm{TM}}$ software (Thermo Fisher, Foster City, CA, USA). BAM files were also manually checked on IGV (Integrative Genomics Viewer) [34].

\subsection{Classification of TP53 Mutations}

Each TP53 missense mutation was assigned a residual transcriptional activity score (TP53 $\left.{ }_{\text {RTAS }}\right)$ according to the results of a site-directed mutagenesis technique and yeast-based functional assay $[17,18]$. The TP53 $3_{\text {RTAS }}$ represents the median transcriptional activity value measured across eight different p53-responsive elements. Based on these functional scores, TP53 missense mutations were then divided into two distinct groups: TP5 $3_{\text {RTAS }} \geq 1 \%$ and TP53 $3_{R T A S}<1 \%$. This categorization denotes a clear distinction between a transcriptionally inactive group $\left(T P 53_{\text {Inactive }}=T P 53_{R T A S}<1 \%\right)$ versus a transcriptionally active group $\left(T P 53_{\text {Active }}=T P 53_{R T A S} \geq 1 \%\right)$. Carriers of non-missense mutations including nonsense and frameshift mutations were merged into a third mutational group. 


\subsection{VEGF and VEGFR Analyses}

A gastric adenocarcinoma dataset was collected from the TCGA Pan-Cancer Atlas (https://www. cancer.gov.tcga) for the analysis of mRNA expression, copy number alterations, and mutational data of genes of interest. Tumors with TP53 gene sequencing were selected and those with more than one TP53 alteration were excluded. Individual tumors were then assigned a TP53 mutation-specific RTAS, sub-grouped based on the RTAS, and analyzed for the gene expression and copy gain or loss of VEGF-A, VEGF-C, VEGF-D, and VEGFR2.

\subsection{Statistical Analysis}

The primary endpoint of the study was the overall survival (OS) analysis in carriers of TP53 Inactive mutations in the Ramucirumab/Paclitaxel study group. With 40 events and a $20 \%$ prevalence of the TP53 Inactive mutational status, the scenario for sample size estimation would allow detection of a $66 \%$ reduced risk of death with a power of $80 \%$ and a two-sided type I error of $5 \%$. In the Ramucirumab/Paclitaxel group, OS was calculated from the date of the first cycle of the second-line therapy to the date of death or last follow-up. In the chemotherapy control group, OS was calculated from the date of the first cycle of the first-line therapy to the date of death or last follow-up. The Kaplan-Meier method was used to estimate survival curves and the log-rank test was used to compare survival times between groups. A multivariate Cox proportional hazards model was adopted for adjusting according to clinical and pathological features. Patients achieving complete response or partial response and patients with stable disease or disease progression were evaluated according to the RECIST criteria and the overall response rate included patients with a complete response and partial response. Contingency tables were analyzed by the Chi-square test. All reported $p$-values were two-sided, and confidence intervals (CIs) were at the 95\% level. A $p$-value $<0.05$ was considered statistically significant. Survival analyses were performed using MedCalc for Windows, version 15.0 (MedCalc Software, Ostend, Belgium). Data processing for the VEGF/VEGFR analyses in gastric cancer tissue was completed using R statistical environment version 3.6.2 and figures were generated using GraphPad Prism version 6.07.

\section{Conclusions}

The limitation of this study is the relative sample size, so our findings warrant further investigations to confirm the association between transcriptionally inactive TP53 missense mutations and improved clinical outcomes of patients with metastatic gastric adenocarcinoma who received anti-VEGFR2 plus Paclitaxel systemic therapy. From a clinical perspective, the TP5 $3_{R T A S}$ mutational analysis might improve the identification of patients who are likely to have the greatest benefit from Ramucirumab therapy. Ramucirumab and chemotherapy failed to achieve significant survival advantages in a randomized phase III study when adopted as a first-line therapy for metastatic gastric cancer [35]. In the overall treatment strategy for the metastatic disease, the selection of patients according to TP53 $R$ RAS mutational status represents a promising model to tailor treatment choices and improve clinical outcomes. In addition, TP53 $3_{\text {RTAS }}$ analysis could be evaluated in patients with metastatic adenocarcinomas in other solid tumors with frequent TP53 mutations and where anti-VEGF therapy is commonly employed.

Author Contributions: Conceptualization, F.G., N.W.F., J.G., M.M., and A.R.; data curation, F.G., N.W.F., I.B., M.D.B., S.L., B.V., G.P., L.F., E.O., G.A., R.B., M.P., D.M., J.G., M.F., F.L., D.S., M.D.P., V.C., P.A., M.M., and A.R.; formal analysis, F.G., N.W.F., J.G., M.M., and A.R.; investigation, F.G., N.W.F., M.D.B., S.L., B.V., G.P., L.F., E.O., G.A., R.B., M.P., D.M., J.G., M.F., F.L., M.D.P., V.C., P.A., and A.R.; methodology, F.G., N.W.F., I.B., J.G., and A.R.; project administration, F.G. and A.R.; resources, M.M.; writing—original draft, F.G., N.W.F., and A.R.; writing-review and editing, F.G., N.W.F., I.B., M.D.B., S.L., B.V., G.P., L.F., E.O., G.A., R.B., M.P., D.M., J.G., M.F., F.L., D.S., M.D.P., V.C., P.A., M.M. and A.R. All authors have read and agreed to the published version of the manuscript.

Funding: This study has been financially supported by FanoAteneo, Italy. 
Acknowledgments: All patient information and pathology materials were collected under a protocol approved by the Regional Ethical Committee. The Authors agree for the publication.

Conflicts of Interest: The authors declare no conflict of interest.

\section{References}

1. Sabapathy, K.; Lane, D. Therapeutic Targeting of p53: All Mutants are Equal, but Some Mutants are more Equal than Others. Nat. Rev. Clin. Oncol. 2017, 15, 13-30. [CrossRef] [PubMed]

2. Muller, P.A.J.; Vousden, K.H. Mutant p53 in Cancer: New Functions and Therapeutic Opportunities. Cancer Cell 2014, 25, 304-317. [CrossRef] [PubMed]

3. Ghahremani, M.F.; Goossens, S.; Nittner, D.; Bisteau, X.; Bartunkova, S.; Zwolinska, A.; Hulpiau, P.; Haigh, K.; Haenebalcke, L.; Drogat, B.; et al. p53 Promotes VEGF Expression and Angiogenesis in the Absence of an Intact p21-Rb Pathway. Cell Death Differ. 2013, 20, 888-897. [CrossRef] [PubMed]

4. Ravi, R.; Mookerjee, B.; Bhujwalla, Z.M.; Sutter, C.H.; Artemov, D.; Zeng, Q.; Dillehay, L.E.; Madan, A.; Semenza, G.L.; Bedi, A. Regulation of Tumor Angiogenesis by p53-Induced Degradation of Hypoxia-Inducible Factor $1 \alpha$. Genome Res. 2000, 14, 34-44.

5. Hayashi, Y.; Tsujii, M.; Kodama, T.; Akasaka, T.; Kondo, J.; Hikita, H.; Inoue, T.; Tsujii, Y.; Maekawa, A.; Yoshii, S.; et al. p53 Functional Deficiency in Human Colon Cancer Cells Promotes Fibroblast-Mediated Angiogenesis and Tumor Growth. Carcinogenesis 2016, 37, 972-984. [CrossRef] [PubMed]

6. Qin, G.; Kishore, R.; Dolan, C.M.; Silver, M.; Wecker, A.; Luedemann, C.N.; Thorne, T.; Hanley, A.; Curry, C.; Heyd, L.; et al. Cell Cycle Regulator E2F1 Modulates Angiogenesis via p53-Dependent Transcriptional Control of VEGF. Proc. Natl. Acad. Sci. USA 2006, 103, 11015-11020. [CrossRef]

7. Pfister, N.T.; Fomin, V.; Regunath, K.; Zhou, J.Y.; Zhou, W.; Silwal-Pandit, L.; Freed-Pastor, W.A.; Laptenko, O.; Neo, S.P.; Bargonetti, J.; et al. Mutant p53 Cooperates with the SWI/SNF Chromatin Remodeling Complex to Regulate VEGFR2 in Breast Cancer Cells. Genes Dev. 2015, 29, 1298-1315. [CrossRef]

8. Schwaederle, M.; Lazar, V.; Validire, P.; Hansson, J.; Lacroix, L.; Soria, J.-C.; Pawitan, Y.; Kurzrock, R.; Vladimir, L. VEGF-A Expression Correlates with TP53 Mutations in Non-Small Cell Lung Cancer: Implications for Antiangiogenesis Therapy. Cancer Res. 2015, 75, 1187-1190. [CrossRef]

9. Li, A.M.; Boichard, A.; Kurzrock, R. Mutated TP53 is a Marker of Increased VEGF Expression: Analysis of 7525 Pan-Cancer Tissues. Cancer Boil. Ther. 2019, 21, 95-100. [CrossRef]

10. Joshi, H.; Bhanot, G.; Børresen-Dale, A.-L.; Kristensen, V. Potential Tumorigenic Programs Associated with TP53 Mutation Status Reveal Role of VEGF Pathway. Br. J. Cancer 2012, 107, 1722-1728. [CrossRef]

11. Said, R.; Hong, D.S.; Warneke, C.L.; Lee, J.J.; Wheler, J.J.; Janku, F.; Naing, A.; Falchook, G.S.; Fu, S.; Piha-Paul, S.A.; et al. P53 Mutations in Advanced Cancers: Clinical Characteristics, Outcomes, and Correlation between Progression-Free Survival and Bevacizumab-Containing Therapy. Oncotarget 2013, 4, 705-714. [CrossRef] [PubMed]

12. Wheler, J.J.; Janku, F.; Naing, A.; Li, Y.; Stephen, B.; Zinner, R.; Subbiah, V.; Fu, S.; Karp, D.; Falchook, G.S.; et al. TP53 Alterations Correlate with Response to VEGF/VEGFR Inhibitors: Implications for Targeted Therapeutics. Mol. Cancer Ther. 2016, 15, 2475-2485. [CrossRef] [PubMed]

13. Hsu, H.-C.; You, J.-F.; Chen, S.-J.; Chen, H.-C.; Yeh, C.-Y.; Tsai, W.-S.; Hung, H.-Y.; Yang, T.-S.; Lapke, N.; Tan, K.-T. TP53 DNA Binding Domain Mutations Predict Progression-Free Survival of Bevacizumab Therapy in Metastatic Colorectal Cancer. Cancers 2019, 11, 1079. [CrossRef] [PubMed]

14. Mallen, A.; Filiaci, V.; Levine, D.; Thiel, K.; Aghajanian, C.; Meng, X.; Devor, E.; Moore, K.; Powell, M.; Secord, A.; et al. Evidence for Synthetic Lethality between Bevacizumab and Chemotherapy in Advanced, p53 Null Endometrial Cancers. Gynecol. Oncol. 2018, 149, 29-30. [CrossRef]

15. Koehler, K.; Liebner, D.; Chen, J.L. TP53 Mutational Status is Predictive of Pazopanib Response in Advanced Sarcomas. Ann. Oncol. 2016, 27, 539-543. [CrossRef]

16. Cao, X.; Hou, J.; An, Q.; Assaraf, Y.G.; Wang, X. Towards the Overcoming of Anticancer Drug Resistance Mediated by p53 Mutations. Drug Resist. Updat. 2020, 49, 100671. [CrossRef]

17. Fischer, N.W.; Prodeus, A.; Gariépy, J. Survival in Males with Glioma and Gastric Adenocarcinoma Correlates with Mutant p53 Residual Transcriptional Activity. JCI Insight 2018, 3, 15. [CrossRef] 
18. Kato, S.; Han, S.-Y.; Liu, W.; Otsuka, K.; Shibata, H.; Kanamaru, R.; Ishioka, C. Understanding the Function-Structure and Function-Mutation Relationships of p53 Tumor Suppressor Protein by High-Resolution Missense Mutation Analysis. Proc. Natl. Acad. Sci. 2003, 100, 8424-8429. [CrossRef]

19. Tan, P.; Guan, Y.K. Genetics and Molecular Pathogenesis of Gastric Adenocarcinoma. Gastroenterology 2015, 149, 1153-1162. [CrossRef]

20. Casak, S.J.; Fashoyin-Aje, I.; Lemery, S.J.; Zhang, L.; Jin, R.; Li, H.; Zhao, L.; Zhao, H.; Zhang, H.; Chen, H.; et al. FDA Approval Summary: Ramucirumab for Gastric Cancer. Clin. Cancer Res. 2015, 21, 3372-3376. [CrossRef]

21. Khan, U.; Shah, M.A. Ramucirumab for the Treatment of Gastric or Gastro-Esophageal Junction Cancer. Expert Opin. Boil. Ther. 2019, 19, 1135-1141. [CrossRef] [PubMed]

22. Wahl, A.F.; Donaldson, K.L.; Fairchild, C.; Lee, F.Y.; Foster, S.A.; Demers, G.W.; Galloway, D.A. Loss of Normal p53 Function Confers Sensitization to Taxol by Increasing G2/M Arrest and Apoptosis. Nat. Med. 1996, 2, 72-79. [CrossRef] [PubMed]

23. Jean, S.; Li, J.; Katsaros, D.; Wubbenhorst, B.; Maxwell, K.N.; Fishbein, L.; McLane, M.W.; Benedetto, C.; Canuto, E.M.; Mitra, N.; et al. Paclitaxel is Necessary for Improved Survival in Epithelial Ovarian Cancers with Homologous Recombination Gene Mutations. Oncotarget 2016, 7, 48577-48585. [CrossRef]

24. Bocci, G.; Di Paolo, A.; Danesi, R. The Pharmacological Bases of the Antiangiogenic Activity of Paclitaxel. Angiogenesis 2013, 16, 481-492. [CrossRef] [PubMed]

25. King, C.; Hristova, K. Direct Measurements of VEGF-VEGFR2 Binding Affinities Reveal the Coupling between Ligand Binding and Receptor Dimerization. J. Boil. Chem. 2019, 294, 9064-9075. [CrossRef]

26. Stiewe, T.; Haran, T.E. How Mutations Shape p53 Interactions with the Genome to Promote Tumorigenesis and Drug Resistance. Drug Resist. Updat. 2018, 38, 27-43. [CrossRef]

27. Khromova, N.V.; Kopnin, P.B.; Stepanova, E.V.; Agapova, L.S.; Kopnin, B.P. p53 Hot-Spot Mutants Increase Tumor Vascularization via ROS-Mediated Activation of the HIF1/VEGF-A Pathway. Cancer Lett. 2009, 276, 143-151. [CrossRef]

28. Zhou, X.; Hao, Q.; Lu, H. Mutant p53 in Cancer Therapy-The Barrier or the Path. J. Mol. Cell Boil. 2018, 11, 293-305. [CrossRef]

29. Sethi, N.; Kikuchi, O.; McFarland, J.; Zhang, Y.; Chung, M.; Kafker, N.; Islam, M.; Lampson, B.; Chakraborty, A.; Kaelin, W.G.; et al. Mutant p53 Induces a Hypoxia Transcriptional Program in Gastric and Esophageal Adenocarcinoma. JCI Insight 2019, 4, 15. [CrossRef]

30. The Cancer Genome Atlas Research Network Comprehensive Molecular Characterization of Gastric Adenocarcinoma. Nature 2014, 513, 202-209. [CrossRef]

31. De Braud, F.; Niger, M.; Tirino, G.; Pappalardo, A.; Berenato, R.; Laterza, M.M.; Pietrantonio, F.; Morano, F.; Antista, M.; Lonardi, S.; et al. Ramucirumab as Second-Line Therapy in Metastatic Gastric Cancer: Real-World Data from the RAMoss Study. Target. Oncol. 2018, 13, 227-234.

32. Catalano, V.; Graziano, F.; Santini, D.; D’Emidio, S.; Baldelli, A.M.; Rossi, D.; Vincenzi, B.; Giordani, P.; Alessandroni, P.; Testa, E.; et al. Second-Line Chemotherapy for Patients with Advanced Gastric Cancer: Who May Benefit? Br. J. Cancer 2008, 99, 1402-1407. [CrossRef] [PubMed]

33. McShane, L.M.; Altman, D.G.; Sauerbrei, W.; Taube, S.E.; Gion, M.; Clark, G.M. Reporting recommendations for tumor marker prognostic studies. J. Clin. Oncol. 2005, 23, 9067-9072. [CrossRef] [PubMed]

34. Robinson, J.T.; Thorvaldsdóttir, H.; Winckler, W.; Guttman, M.; Lander, E.S.; Getz, G.; Mesirov, J.P. Integrative Genomics Viewer. Nat. Biotechnol. 2011, 29, 24-26. [CrossRef] [PubMed]

35. Fuchs, C.S.; Shitara, K.; Di Bartolomeo, M.; Lonardi, S.; Al-Batran, S.-E.; Van Cutsem, E.; Ilson, D.H.; Alsina, M.; Chau, I.; Lacy, J.; et al. Ramucirumab with Cisplatin and Fluoropyrimidine as First-Line Therapy in Patients with Metastatic Gastric or Junctional Adenocarcinoma (RAINFALL): A Double-Blind, Randomised, Placebo-Controlled, Phase 3 Trial. Lancet Oncol. 2019, 20, 420-435. [CrossRef]

(C) 2020 by the authors. Licensee MDPI, Basel, Switzerland. This article is an open access article distributed under the terms and conditions of the Creative Commons Attribution (CC BY) license (http://creativecommons.org/licenses/by/4.0/). 